\title{
ОСОБЛИВОСТІ СТРУКТУРИЗАЦІЇ ЕКСПОРТНОГО ПОТЕНЦІАЛУ ЗЕРНОПРОДУКТОВОГО ПІДКОМПЛЕКСУ АПК
}

\author{
Зрайло Іван Іванович \\ аспірант \\ Львівський національний аграрний університет (м. Дубляни, Львівська обл., Україна) \\ ORCID 0000-0003-3051-8655 \\ I.zrailo@ukr.net
}

Визначено зміст експортного потенціалу зернопродуктового підкомплексу АПК як системну компоненту економічного потенціалу зернопродуктового підкомплексу АПК, організаційно-технічна структура якої підпорядковується місії $і$ цілям комплексу та на яку покладена реалізаційна здатність продукиії (послуг) на світовому ринку. Виділено складові експортного потенціалу зернопродуктового підкомплексу АПК - експортний потенціал галузей ссрери матеріального виробництва; експортний потенціал галузей сфрери послуг; потенціал експортних бар'єрів; потенціал іноземних ринків. Обгрунтовано сутність структуроутворюючих складових експортного потенціалу зернопродуктового підкомплексу АПК.

Ключові слова: експортний потенціал, зернопродуктовий підкомплекс АПК, структура експортного потенціалу.

DOI: https://doi.org/10.32845/bsnau.2019.4.25

Постановка проблеми. Забезпечення ефективного функціонування вітчизняного зернопродуктового підкомплексу (ЗП) є однією з найактуальніших проблем розвитку усього АПК держави, адже зерновиробництво, окрім важливого соціально-економічного, має ще й політичне значення для розвитку національної економіки. Зерно завжди належало до конкурентоспроможних продуктів на світовому ринку і може бути вагомим важелем впливу на світову економіку. Сприятливі передумови для виробництва зерна в Україні є основою формування експортного потенціалу зернопродуктового підкомплексу АПК, який може забезпечити державний бюджет стабільними надходженнями валюти.

Аналіз останніх досліджень та публікацій. Обговорення проблем формування і розвитку зернопродуктового підкомплексу в економічних дослідженнях розпочалося в 20-30 pp. XX століття, де акцент ставився на процеси концентрації і комбінування сільського господарства і промисловості. В наукових публікаціях 70-90рр. в більшій мірі розглядалися питання щодо максимізації виробництва продукції АПК за рахунок дотримання оптимального співвідношення між сферами продуктових підкомплексів, технологічної узгодженості і економічної зацікавленості усіх галузей АПК (Ільїна І.В., Сидоренко О.В.) [1]; необхідності впливу НТП на досягнення стійкого розвитку сільського господарства (Ємельянов А.М. [2], Кісельов В.І. [3], Худолій Л. [4]); зміцнення продовольчої безпеки (Бенсон К., Грін Р. [5], Ейде В.Б. [6], Ейхер К., Дж. Штаац [7]); посилення агропромислової інтеграції (Лобас М. Г. [8], Толмачов О.В. [9]), включення галузей і сфер в склад продуктових підкомплексів (Душин Б.В. [10]). Сучасний науковий доробок представлений в працях таких відомих економістів як Гайдуцький П.І. [11], Погріщук Б.В. [12], Мельник Л.Л. [13], Світовий О.М. [14], Черевко Г.В. [15], Колодійчук В.А. [16], Шпичак О.М. [17] та ін.

Теоретичні і прикладні аспекти дослідження експортного потенціалу відображені в наукових працях вітчизняних та зарубіжних науковців, таких як: Сейфуллаєва М. Е. [18], Капіцин В. М., Рогачов В. В. [19], Волкодавова О. В. [20], Геєць В. М. [21], Семиноженко В. П., Кваснюк Б. Є., Мельник Т.М. [22], Чичкало-Кондрацька І.Б. [23], Селезньова К.В. [24] та ін. Широкий плюралізм думок у цій сфері зумовлено складним системним механізмом формування і реалізації експортного потенціалу, який $є$ багатогранним і багатоаспектним процесом, що охоплює як внутрішньоекономічні, так і зовнішньоекономічні складові та чинники.

Втім, проведення комплексного аналізу цілісного розвитку зернопродуктового підкомплексу, виявлення перспектив його розвитку, розробка моделі формування експортного потенціалу зернопродуктового підкомплексу АПК потребують проведення подальших досліджень з обґрунтуванням низки концептуальних моментів.

Метою статті наукове обґрунтування структури експортного потенціалу зернопродуктового підкомплексу АПК.

Виклад основного матеріалу. Враховуючи існуючі теоретичні напрацювання щодо з'ясування сутності понять «експертний потенціал» та «зернопродуктовий комплекс» пропонуємо розглядати експортний потенціал зернопродуктового підкомплексу АПК як системну компоненту економічного потенціалу зернопродуктового підкомплексу АПК, організаційно-технічна структура якої підпорядковується місії і цілям комплексу та на яку покладена реалізаційна здатність продукції (послуг) на світовому ринку.

Відтак, експортний потенціал досліджуємо у рамках економічного потенціалу як його складову, в якій відображаються можливості економічної системи інтегруватись у світовий економічний простір.

Науковець Уліганинець Г. [25] зазначає, що формування економічного потенціалу галузі, регіону чи суспільства в цілому, залежить від потенціалу нижчих ієрархічних рівнів господарювання - підприємств та домогосподарств. Відповідно, з метою ефективного управління ним, в системі економічного потенціалу варто виділяти окремі підсистеми (компоненти) - ресурсний, природний, виробничий, трудовий, інноваційний та інші потенціали. Кількість компонент, що додається до економічного потенціалу, залежить від суспільного розвитку. Розвиток знаннєвої, соціально-орієнтованої економіки спонукав до виокремлення таких компонент як, наприклад, науково-технічна, інфоормаційна інтелектуальна, маркетингова, соціальна, культурна. На нашу думку, структура економічного потенціалу зернопродуктового підкомплексу АПК в сучасних умовах суспільного розвитку повинна враховувати виробничий, інноваційний, фінансовий, інфоормаційний, кадрово-інтелектуальний, організаційно-управлінський, науково-технічний, інфрраструктурний, експортний, маркетинговий, соціально-культурний потенціали, а також 
потенціали знань та відтворення. При цьому, експортній компоненті в наведеній структурі відведено провідне місце, адже характерною основою розвитку України є загальна її зосередженість на дослідженні проблематики ефективного виходу та функціонування вітчизняного ЗП АПК на глобальний ринок і посідання в ньому гідного місця.

Процес формування експортного потенціалу ЗП АПК $€$ складним, динамічним процесом, націленим на взаємодію зі зовнішнім середовищем і забезпечення високої якості реалізації. Розвиток, збалансованість і есрективність використання його структурних компонентів обумовлюють чинники зовнішнього (економічні, соціальні політичні, інституціональні, ринкові) і внутрішнього (стратегія розвитку підкомплексу (комплексу), менеджмент, фінанси, кадри, інвестиції тощо) середовища. Окремі дослідники $[23,24]$ розмежовують чинники за ієрархічними рівнями їх впливу на: мікро- (рівень інноваційної активності підприємства, кваліфікація персоналу, фрінансовий стан підприємств, якість продукції), мезо(рівень модернізації галузей та виробництв, підтримка місцевих органів самоврядування, сезонність виробництва, рівень конкуренції в галузі), макро- (норми національного законодавства, політичні реформи, курс національної валюти, воєнні конфлікти, економічні блокади, якість систем сертифікації контролю якості експортної продукції, транспортна інфраструктура, умови кредитування) та мегарівні (рівень міжнародної конкуренції, світовий рейтинг надійності країни для кредитів та інвестицій, рівень дискримінації експортерів за кордоном).

Зазначимо, що експортний потенціал ЗП АПК тісно пов'язаний з його конкурентними перевагами на міжнародному ринку та залежить, на думку науковця Радченко Е.Є., від географрічного розташування країни; економічних, природно-кліматичних, соціокультурних, інфраструктурних, наукових, інноваційних, трудових, технологічних, інвестиційних та історичних умов діяльності економічних суб'єктів; правового, політичного та економічного середовища ведення міжнародного бізнесу[26].

В цілому, при формуванні та використанні потенціалу проводиться його декомпозиція на елементи, встановлюються їх функціональні зв'язки, тобто проводиться структуризація. Чіткого уявлення про структуру експортного потенціалу поки не ссрормовано, що пов'язано з його розглядом на різних ієрархічних рівнях та в розрізі окремих проявів потенціалу. Так, експортний потенціал країни, на думку А. Тимофеєнко [27], сумарно складається із регіональних потенціалів. А.Мазаракі [28], К.Селезньова [29] в його структурі виділяють експортний потенціал окремих галузей, а в їх межах експортні потенціали окремих підприємств.
Науковець Н. М. Чухраєва [30] до експортного потенціалу відносить такі його основні елементи: внутрішній потенціал національної економіки або потенціал пропозиції (сировинний, виробничий. фінансовий, маркетинговий, людський, інвестиційний тощо), потенціал зарубіжних ринків або потенціал попиту (потенціал існуючого попиту, потенціал зростання попиту, ключові чинники успіху, зовнішньополітичний клімат) та системи бар'єрів і стимулів для експортної продукції (внутрішні стимули і обмеження експорту; зовнішні бар'єри: тарифні і нетарифні обмеження).

В працях М. Сейфуллаєвої, В.Капіцина [18] експортний потенціал регіону є комплексною характеристикою, що включає такі компоненти: ресурсно-сировинну, промислову, фінансову, організаціно-технічну, маркетингову, кадрову, соціально-культурну, інфрраструктурну, науково-інноваційну, інвестиційну. На нашу думку, такий підхід в більшій мірі розкриває експортний потенціал як сукупність експортних ресурсів, залучених у виробництво та підготовлених до реалізації. Це, за сутністю відображає категорію виробничого потенціалу. А решта компонент, такі як соціально-культурна, інфраструктурна, науково-інноваційна та інвестиційна характеризують економічний потенціал регіону в цілому.

Структуру експортного потенціалу окремої сфрери, зокрема виробничої, запропоновано розглядати з точки зору активної і пасивної її складових. Так, до активної складової віднесено інвестиційний, інтелектуальний, інституціональний, технологічний, соціокультурний потенціали та інфраструктуру. До пасивної - природні ресурси, кон'юнктуру ринку, стандартизацію, сертифікацію [31].

Узагальнюючи підходи до структуризації експортного потенціалу вважаємо, що структура експортного потенціалу 3П АПК повинна охоплювати (рис. 1): 1) експортний потенціал галузей сфери матеріального виробництва ЗП АПК; 2) експортний потенціал галузей сфери послуг ЗП АПК; 3) потенціал експортних бар'єрів; 4) потенціал іноземних ринків.

Експортний потенціал галузей сфери матеріального виробництва ЗП АПК (сільське господарство, промисловість та ін.) повинен забезпечити продукування конкурентоспроможної продукції, котра може стати об'єктом зовнішньої торгівлі, тоді як потенціал галузей сфери послуг (освіта, наука, й наукове обслуговування, фінансування, кредитування та страхування, сфера управління) повинен забезпечити надання послуг невиробничого та виробничого характеру щодо розробки, супроводу, організації виробничого процесу з виготовлення та реалізації експортоорієнтованої продукції. Обидві сфери і окремі галузі тісно взаємопов'язані між собою, впливають одна на одну, формуючи галузеву структуру зернопродуктового підкомплексу АПК. 


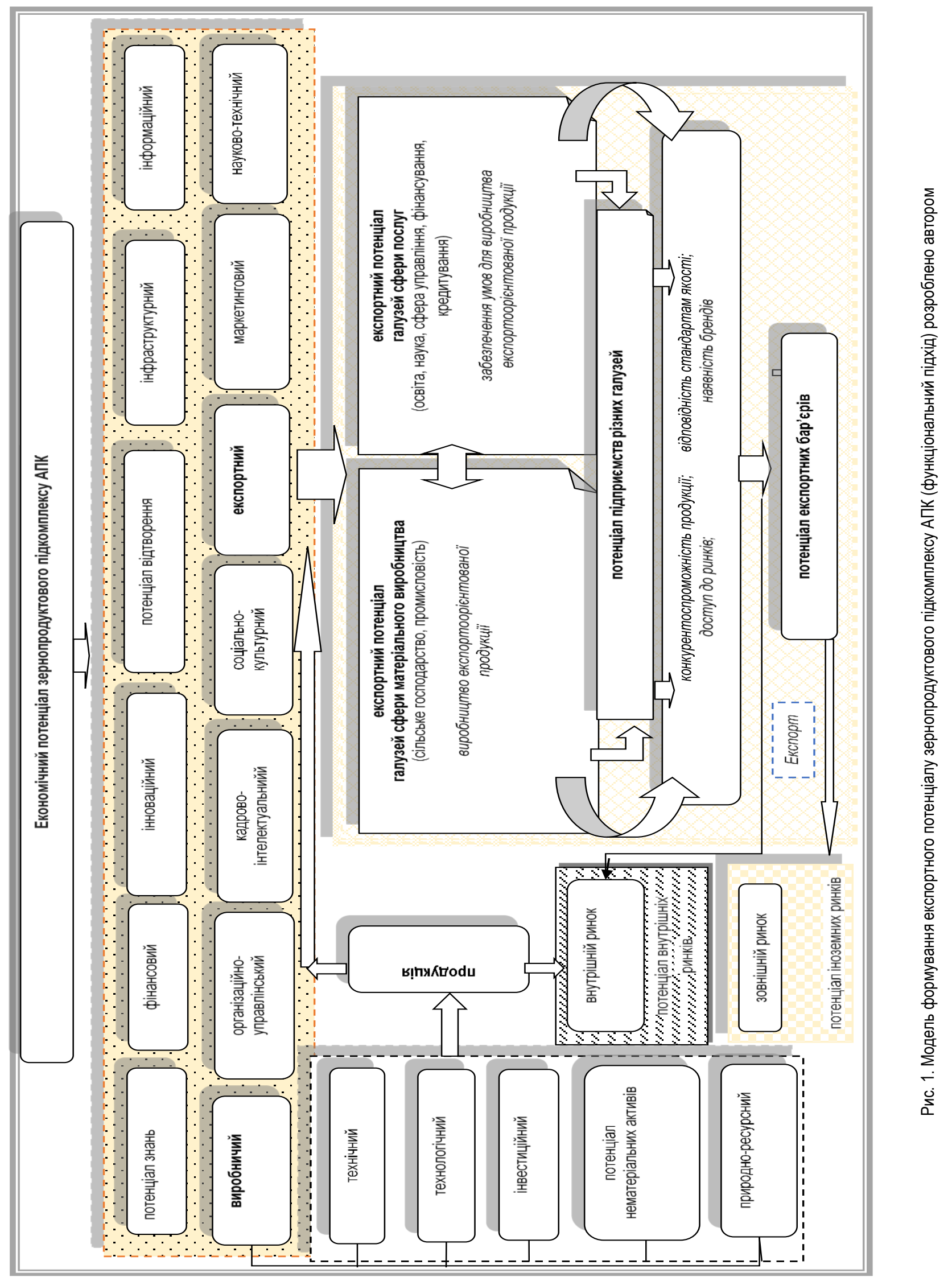

Так, наприклад, промисловість чи сільське господар- $\mid$ освіти та науки. У свою чергу, ці установи не можуть обійтися ство потребує кваліфікованих фахівців, яких готують заклади 
без певного навчального, дослідницького обладнання, техніки, що виробляють промислові підприємства. В умовах стрімкого розвитку НТП, наука займає особливе місце у структурі АПК, суттєво впливаючи на вдосконалення і розвиток виробництва. Хочемо також зазначити, що реалізація експортного потенціалу галузі здійснюється на рівні підприємства як суб'єкта зовнішньоекономічної діяльності. Саме експортний потенціал підприємства виступає основою ланцюга формування експортного потенціалу зернопродуктового підкомплексу АПК.

Потенціал експортних бар'єрів є важливою структурною ланкою експортного потенціалу ЗП АПК. Як було зазначено вище, експортний потенціал в цілому визначаються низкою політичних, економічних, соціальних та інших чинників, які зазвичай мають різноспрямовану дію та, відповідно, формують тенденції й особливості експортної діяльності на рівні окремої країни, регіону, галузі. Водночас, безпосередніми учасниками міжнародної торгівлі є підприємства, ефективність господарської діяльності яких великою мірою залежить від економічного та регуляторного середовища, у якому оперує бізнес. Тому визначення бар'єрів, з якими зіштовхуються експортери на мікрорівні, є вихідним пунктом розробки політики сприяння експорту.

Основними експортними бар'єрами виступають тарифні (мита, квоти) і нетарифні обмеження (відшкодування ПДВ, валютний контроль). Сьогодні у міжнародній торгівлі на перший план вийшли нетарифні обмеження, тобто заходи політики, які не відносяться до звичайних мит, але які можуть потенційно впливати на міжнародну торгівлю шляхом зміни обсягів торгівлі або цін, або обсягів та цін одночасно [32]. Їх застосування у світі постійно зростає.

Найбільшими проблемами, з якими зіштовхуються вітчизняні експортери, за оцінками експертів Світового економічного форуму є: відсутність доступу до торговельного фі- нансування (16\%), неналежний рівень технологій виробництва й навичок персоналу (13,7\%), труднощі у виявленні потенційних ринків і покупців (13,6\%), недостатня відповідність продукції міжнародним технічним вимогам і стандартами $(11,1 \%)$, а також проблеми доступу до імпортних ресурсів за конкурентними цінами $(9,4 \%)$ [33].

І остатній, структуроутворюючий елемент, - потенціал іноземних ринків, що враховує існуючий попит на ринку, потенціал зростання попиту, а також зовнішньополітичний клімат, правове та економічне середовища ведення міжнародного бізнесу - створює можливості для реалізації експортного потенціалу ЗП АПК. Зрозуміло, що вітчизняна продукція повинна відповідати стандартам якості, бути конкурентоспроможною, знаною на ринку, оскільки існує тісний взаємозв'язок між підвищенням її конкурентоспроможності на світовому ринку та збільшенням експортного потенціалу ЗП АПК в цілому.

Додамо, що важливість і необхідність дослідження експортного потенціалу зернопродуктового підкомплексу АПК як складної багаторівневої системи визначається передусім актуальністю імперативів державної політики у сфері забезпечення продовольчої безпеки держави, а також формуванням зовнішньоекономічного потенціалу держави.

Висновки. Отже, формування експортного потенціалу ЗП АПК є комплексним завданням, яке має виконуватись з консолідацією зусиль на різних управлінських рівнях. Експортний потенціал зернопродуктового підкомплексу є спроможністю АПК виявляти й постійно відтворювати свої конкурентні переваги на світовому ринку відповідно до умов середовища, що постійно змінюється. Експортний потенціал ЗП АПК виступає як складно організована динамічна категорія, структура якої охоплює експортний потенціал галузей сфери матеріального виробництва ЗП АПК, експортний потенціал галузей сфрери послуг ЗП АПК, потенціал експортних бар'єрів та потенціал іноземних ринків.

\section{Список використаної літератури:}

1. Ильина И.В., Сидоренко О.В., Морозова Е.В. Роль фондообразующих отраслей АПК в решении продовольственной проблемы регионов. Национальные интересы: приоритеты и безопасность. 2012. № 2. С. 30-36.

2. Емельянов А.М., Иевлев А.И., Никонов А.А. и др. Интенсивное развитие АПК. М.: Агропромиздат, 1987. 303 с.

3. Киселев В.И. АПК: совершенствование хозяйственного механизма. М.: Агропромиздат, 1985. 240 с.

4. Худолій Л. Економічний механізм формування і функціонування ринку зерна в Україні. К. : IAE, 1998. 211 c

5. Benson C., Clay E. J., Green R. H. Food Security in Sub-Saharan Africa, IDS. Brighton : University of Sussex, 1986. P. 2-6.

6. Eide W. B. Proceedings of the Agriculture. Nutrition Linkage Workshop, Virginia. 1990. Vol. 1. P. 35-36.

7. Eicher C. K., Staatz J. M. Agricultural Development in the Third World. Baltimore : John Hopkins University Press, 1990.

8. Лобас М. Г. Розвиток зернового господарства. К. : Агроінком, 1997. 448 с.

9. Толмачев, А. В. Экономика и организация производства в зернопродуктовом подкомплексе АПК (методология и практика решений) : автореферат диссертации на соискание уч. степени докт. эконом. наук: спец. 08.00.05 «Экономика и управление народным хозяйством». М. 1998. 44 с.

10. Душин Б.В. Структура АПК: Днепропетровск. - Сельскохоз. Ин- т. Днепропетровск, 1986. 19 с.

11. Гайдуцький П. І. Структурні перекоси і ризики кризи в АПК. Економіка АПК. 2014. № 7. С. 38-46.

12. Погріщук Б.В. Організаційно-економічні умови функціонування зернопродуктового підкомплексу України: аспекти оптимізації. Агросвіт. 2010. № 4. С. 13-17.

13. Мельник Л.Л. Зерновий комплекс України в аспекті експортних можливостей та державного регулювання. АгроСвіт. 2013. № 4. С. 13-19.

14. Світовий О.М. Шляхи оптимізації виробництва у зернопродуктовому підкомплексі для збільшення доданої вартості. Економіка АПК. 2016. № 2. С. 52-58.

15. Черевко Г. В. та ін. Економіка зернопродуктового комплексу АПК. Львів: Українські технологї̈. 2000. 198 с.

16. Колодійчук В.А. Галузеве позиціонування зернопродуктового підкомплексу АПК України. Економічний часописXXI. 2014. № 9-10(1). C. 45-48. 
17. Шпичак О.М., Боднар О.В. Вигоди та проблеми експорту зерна з України. Економіка АПК. 2013. № 10. С. 5-15.

18. Сейфуллаева М. Э., Капицын В. М. Экспортный потенциал российских регионов в условиях глобализации мировой экономики. Маркетинг. 2001. № 1. С. 6.

19. Рогачов В.В.Экспортный потенциал Росси: состояние, ориентиры и условия развития. Внешнеэкономический бюллетень. № 5.2004.

20. Волкодавова Е. В. Экспортный потенциал промышленных предприятий: теория, методология, практика. Самара. Самар. гос. экон. ун-та, 2007.

21. Гейць В. М., Семиноженка В. П., Кваснюка Б. Є. Стратегічні виклики XXI століття суспільству та економіці України. К.: Фенікс, 2007

22. Мельник Т. Експортний потенціал України : методологія оцінки та аналіз. Міжнародна економічна політика. 2008. № 8-9. C. 221-224.

23. Чичкало-Кондрацкая И.Б., Радченко Л.Н. Анализ моделей управления экспортным потенциалом стран мира. Економічний часопис-XXI. 2013. № 5-6. С. 7-10.

24. Селезньова К.В. Обґрунтування факторів впливу на розвиток експортного потенціалу машинобудівного підприємства. Вісник НТУ «ХПІ». 2013. № 45(1018). С. 102-115.

25. Уліганинець Г.П. До питання про сутність терміну «економічний потенціал». Наука: теория и практика 2007. URL: http://www.rusnauka.com/14.NTP_2007/Economics/21654.doc.htm

26. Радченко Е.Є. Визначення сутності поняття «експортний потенціал країни». Вчені записки Університету «КРОК». 2013. Вип. 34. С. 205-212.

27. Тимофеєнко С.А. Визначення зовнішньоекономічного потенціалу регіонів України (на прикладі Одеської області). Науковий вісник Національного університету державної податкової служби України (економіка, право). 2014. № 1. С. 77-84.

28. Мазаракі А.А. Управління експортним потенціалом України. Київ. нац. торг.-екон. ун-т. - К. : Київ. нац.торг.-екон. ун-т, 2007. $210 \mathrm{c}$.

29. Селезньова К.В. Обґрунтування фракторів впливу на розвиток експортного потенціалу машинобудівного підприємства. Вісник НТУ «ХП|». 2013. № 45.

30. Чухраєва Н. М. Сутність та структура експортного потенціалу промислових підприємств. Держава та регіони. Серія : Економіка та підприємництво. 2017. № 4-5. С. 73-77.

31. Герушенко Ю.О. Експортний потенціал сфери виробництва як фактор підвищення рівня безпеки національної економіки : дис.. канд. екон. наук : 08.00.03. Львів, 2016. 277с.

32. Біла книга. Як реалізовувати експортний потенціал України за умов глобалізації. К., 2016. URL: http://www.ier.com.ua/files/publications/ Books/2016/White_book_export_UKR_2016.pdf.

33. The Global Enabling Trade Report 2014. http://www.weforum.org/reports/global-enabling-trade-report-2014.

\section{References:}

1. Il'ina, I.V., Sidorenko, O.V., Morozova, Ye.V. (2012). Rol' fondoobrazuyushchikh otrasley APK v reshenii prodovol'stvennoy problemy regionov [Il'ina I.V., Sidorenko O.V., Morozova Ye.V. Rol' fondoobrazuyushchikh otrasley APK v reshenii prodovol'stvennoy problemy regionov]. Natsional'nyye interesy: prioritety i bezopasnost' - Natsional'nyye interesy: prioritety i bezopasnost', 2, 30-36.

2. Emel'yanov, A.M., Yevlev, A.Y., Nykonov, A.A. (1987). Yntensyvnoe razvytye APK. [Intensive development of agro-industrial complex]. M. Agropromizdat.

3. Kiselev, V. I. (1985). APK: sovershenstvovanye khozyaystvennoho mekhanyzma [Agroindustrial complex: improving the economic mechanism]. M. Agropromizdat.

4. Khudoliy, L. (1998). Ekonomichnyy mekhanizm formuvannya i funktsionuvannya rynku zerna v Ukrayini [Economic mechanism of formation and functioning of the grain market in Ukraine]. K. : IAE.

5. Benson, C., Clay, E. J., Green, R. H. (1986). Food Security in Sub-Saharan Africa, IDS. Brighton : University of Sussex, $2-6$.

6. Eide, W. B. (1990). Proceedings of the Agriculture. Nutrition Linkage Workshop, Virginia, 1, 35-36.

7. Eicher, C. K., Staatz, J. M. (1990). Agricultural Development in the Third World. Baltimore : John Hopkins University Press.

8. Lobas, M. H. (1997). Rozvytok zernovoho hospodarstva [Development of grain farming]. K. : Ahroinkom.

9. Tolmachev, A. V. (1998). Ékonomyka y orhanyzatsyya proyzvodstva v zernoproduktovom podkomplekse APK (metodolohyya y praktyka reshenyy) [Economics and organization of production in the grain-product subcomplex of the agro-industrial complex (methodology and practice of solutions)]. Abstract of the thesis for the academic degree doct. economy . Sciences: spec. 08.00 .05 "Economics and National Economy Management". 44. Institute.

10. Dushyn, B.V. (1986). Struktura APK [Structure of agro-industrial complex]. Dnepropetrovsk. Agriculture. Dnepropetrovsk

11. Hayduts'kyy, P. I. (2014). Strukturni perekosy i ryzyky kryzy v APK [Structural distortions and risks of crisis in the agroindustrial complex] Ekonomika APK - Economics of agro-industrial complex, 7, 38-46.

12. Pohrishchuk, B. V. (2010). Orhanizatsiyno-ekonomichni umovy funktsionuvannya zernoproduktovoho pidkompleksu Ukrayiny: aspekty optymizatsiyi [Organizational and economic conditions of functioning of the grain product subcomplex of Ukraine: aspects of optimization]. Ahrosvit - Agrosvit, 4, 13-17.

13. Mel'nyk, L.L. (2013). Zernovyy kompleks Ukrayiny v aspekti eksportnykh mozhlyvostey ta derzhavnoho rehulyuvannya [Grain complex of Ukraine in terms of export opportunities and state regulation]. Ahrosvit - Agrosvit, 4, 13-19.

14. Svitovyy, O.M. (2016). Shlyakhy optymizatsiyi vyrobnytstva u zernoproduktovomu pidkompleksi dlya zbil'shennya 
dodanoyi vartosti [Ways to optimize production in the grain subcomplex to increase added value]. Ekonomika APK - Economics of agro-industrial complex, 2, 52-58.

15. Cherevko, H. V. (2000). Ekonomika zernoproduktovoho kompleksu APK [Economics of grain product complex of agroindustrial complex]. Lviv: Ukrainian technologies.

16. Kolodiychuk, V. A. (2014). Haluzeve pozytsionuvannya zernoproduktovoho pidkompleksu APK Ukrayiny [Sectoral positioning of the grain subcomplex of the agro-industrial complex of Ukraine]. Ekonomichnyy chasopys-XXI - Economic Journal-XXI, 910(1), 45-48.

17. Shpychak, O.M., Bodnar, O.V. (2013). Vyhody ta problemy eksportu zerna z Ukrayiny [Benefits and problems of grain export from Ukraine]. Ekonomika APK - Economics of agro-industrial complex, 10, 5-15.

18. Seyfullaeva, M. É., Kapytsyn, V. M. (2001). Éksportnyy potentsyal rossyyskykh rehyonov v uslovyyakh hlobalyzatsyy myrovoy ékonomyky [Export potential of Russian regions in the context of globalization of the world economy]. Marketynh - Marketing, 1,6 .

19. Rohachov, V. V. (2004). Éksportnyy potentsyal Rossy: sostoyanye, oryentyry y uslovyya razvytyya [Russia's export potential: state, benchmarks and conditions of development]. Vneshneékonomycheskyy byulleten - Foreign Economic Bulletin, 5.

20. Volkodavova, E. V. (2007). Éksportnyy potentsyal promyshlennykh predpryyatyy: teoryya, metodolohyya, praktyka [Export potential of industrial enterprises: theory, methodology, practice]. Samara. Samar. state econ. University.

21. Heyts, V. M., Semynozhenka, V. P., Kvasnyuka, B. Ye. (2007). Stratehichni vyklyky XXI stolittya suspil'stvu ta ekonomitsi Ukrayiny [Strategic challenges of the XXI century to society and economy of Ukraine]. K.: Feniks.

22. Mel'nyk, T. (2008). Eksportnyy potentsial Ukrayiny : metodolohiya otsinky ta analiz [Export potential of Ukraine: assessment methodology and analysis]. Mizhnarodna ekonomichna polityka - International economic policy, 8-9, 221-224.

23. Chychkalo-Kondratskaya, Y.B., Radchenko, L.N. (2013). Analyz modeley upravlenyya éksportnym potentsyalom stran myra [Analysis of models for managing the export potential of the world]. Ekonomichnyy chasopys-XXI - Economic Journal-XXI, 5-6, 7-10.

24. Selezn'ova, K.V. (2013). Obgruntuvannya faktoriv vplyvu na rozvytok eksportnoho potentsialu mashynobudivnoho pidpryyemstva [Substantiation of factors influencing the development of the export potential of the machine-building enterprise]. Visnyk NTU «KHPI» - Bulletin of NTU "KhPI", 45(1018), 102-115.

25. Ulihanynets, H.P. (2007). Do pytannya pro sutnist' terminu «ekonomichnyy potentsial» [On the question of the essence of the term "economic potential"]. Nauka: teoryya y praktyka - Science: Theory and Practice. URL: http://www.rusnauka.com/14.NTP_2007/Economics/21654.doc.htm

26. Radchenko, E.Ye. (2013). Vyznachennya sutnosti ponyattya «eksportnyy potentsial krayiny» [Defining the essence of the concept of "export potential of the country"]. Vcheni zapysky Universytetu «KROK» - Scientific notes of KROK University, 34, $205-212$.

27. Tymofeyenko, S. A. (2014). Vyznachennya zovnishn'oekonomichnoho potentsialu rehioniv Ukrayiny (na prykladi Odes'koyi oblasti) [Determining the foreign economic potential of the regions of Ukraine (on the example of Odessa region)]. Naukovyy visnyk Natsional'noho universytetu derzhavnoyi podatkovoyi sluzhby Ukrayiny (ekonomika, pravo) - Scientific Bulletin of the National University of the State Tax Service of Ukraine (economics, law), 1, 77-84.

28. Mazaraki, A. A. (2007). Upravlinnya eksportnym potentsialom Ukrayiny [Management of export potential of Ukraine]. Kiev. nat. trade and economic University.

29. Selezn'ova, K.V. (2013). Obgruntuvannya faktoriv vplyvu na rozvytok eksportnoho potentsialu mashynobudivnoho pidpryyemstva [Substantiation of factors influencing the development of the export potential of the machine-building enterprise]. Visnyk NTU «KHPI» - Bulletin of NTU "KhPI", 45.

30. Chukhrayeva, N. M. (2017). Sutnist' ta struktura eksportnoho potentsialu promyslovykh pidpryyemstv [The essence and structure of the export potential of industrial enterprises]. Derzhava ta rehiony. Seriya: Ekonomika ta pidpryyemnytstvo - State and regions. Series: Economics and Entrepreneurship, 4-5, 73-77.

31. Herushenko, Yu.O. (2016). Eksportnyy potentsial sfery vyrobnytstva yak faktor pidvyshchennya rivnya bezpeky natsional'noyi ekonomiky [Export potential of the sphere of production as a factor in increasing the level of security of the national economy]. Dys. kand. ekon. nauk : 08.00.03. Lviv.

32. White Paper. (2016). Yak realizovuvaty eksportnyy potentsial Ukrayiny za umov hlobalizatsiyi [How to realize Ukraine's export potential in the context of globalization]. K. URL: http://www.ier.com.ua/files/publications/ Books/2016/White_book_export_UKR_2016.pdf

33. The Global Enabling Trade Report (2014). URL: http://www.weforum.org/reports/global-enabling-trade-report-2014.

Zrailo Ivan Ivanovych, postgraduate, Lviv National Agrarian University (Lviv, Ukraine)

Structural peculiarities of export potential of the grain subcomplex of agro-industrial complex

Ensuring the effective functioning of the domestic grain product subcomplex (ZP) is one of the most pressing problems in the development of the entire agro-industrial complex of the state. This is due to the fact that grain production, in addition to important socio-economic, also has political significance for the development of the national economy. In the article we study the export potential within the economic potential as its component, which reflects the possibilities of the economic system to integrate into the world economic space. Grain has always been one of the most competitive products on the world market and can be a significant lever of influence on the world economy. Favorable conditions for grain production in Ukraine are the basis for the formation of the export potential of the grain subcomplex of the agro-industrial complex, which can provide the state budget with stable foreign exchange 
earnings. Therefore, scientific substantiation of the export potential structure of the agro-industrial complex requires further research. The article defines the content of the export potential of the grain subcomplex of the agro-industrial complex. Namely, it is defines as a system component of the economic potential of the grain subcomplex of agro-industrial complex, the organizational and technical structure of which is subject to the mission and objectives of the complex and which is responsible for the sales capacity of products (services) on the world market. The components of the export potential of the grain subcomplex of the agro-industrial complex are highlighted - the export potential of the material production branches; export potential of service industries; potential of export barriers; potential of foreign markets. The essence of the structure-forming components of the export potential of grain of the food subcomplex of agro-industrial complex is substantiated.

Key words: export potential, grain product subcomplex of agro-industrial complex, structure of export potential.

Дата надходження до редакції: 11.11 .2019 р. 